\title{
Development of vegetal probiotic beverage of passion fruit (Passiflora edulis Sims), yam (Dioscorea cayenensis) and Lacticaseibacillus casei
}

\author{
Cinthia Karla Rodrigues do Monte GUEDES ${ }^{1 *}$ (D), Andrei Felipe Loureiro do Monte GUEDES 2 , \\ Joyce Ramos da SILVA ${ }^{3}$, Emanuele Batista Barbosa da SILVA ${ }^{3}$, Eveline Cássia Meira dos SANTOS 3 , \\ Thayza Cristina Montenegro STAMFORD ${ }^{4}$, Tânia Lúcia Montenegro STAMFORD ${ }^{3}$
}

\begin{abstract}
The purpose of this study was to produce a non-dairy functional beverage containing Lacticaseibacillus casei, passion fruit juice, and yam flour. The physical and chemical characteristics, consumer acceptance, viability of $L$. casei during storage time, and resistance to in vitro simulated gastrointestinal tract conditions were investigated. The beverages were considered good sources of fiber and were well accepted in their aroma, color and appearance parameters. The effectiveness of passion fruit to mask the off-flavor of $L$. casei fermentation was confirmed. There were $>10^{6} \mathrm{UFC} . \mathrm{mL}^{-1}$ of the microorganism during storage (28 days) and they were resistant to in vitro simulated gastrointestinal tract conditions $\left(>10^{4} \mathrm{UFC} \cdot \mathrm{mL}^{-1}\right)$. Passion fruit and yam flour showed to be excellent raw materials to be explored and used in combination to promote the probiotic survival and mask the off-flavor, thus being promising alternatives in non-dairy probiotic products development.
\end{abstract}

Keywords: vegetal products; functional foods; novel fermented foods; tropical fruits; yam.

Practical Application: Passion fruit and yam flour showed to be excellent raw materials to promote the probiotic survival and mask the off-flavor. The results of the study can be used in processing probiotic non-dairy products.

\section{Introduction}

Health and wellness are the guiding principles of the food industry. The link between health and intake of selected foods has promoted a greater consumption of functional foods (Martins et al., 2013). The increasing search for functional food, in particular probiotics, is justified by the range of benefits provided to consumers, including the prevention of dysbiosis, decrease of lactose intolerance, enhanced immunological function, and the more recently suggested benefits in the prevention of obesity, a current public health problem (Daliri \& Lee, 2015).

Probiotics are beneficial microorganisms that, when administered in appropriate amounts, contribute to microbial intestinal balance and thus to human health (Hotel \& Córdoba, 2001). Currently new terminologies for all aspects of probiotic benefits have been proposed and described such as 'paraprobiotics' (dead/inactive cells of probiotics) and 'postbiotics' (healthful metabolites of probiotics) because findings have shown that dead cells (intact or ruptured) could also show significant health impacts on human. (Zendeboodi et al., 2020). Lactobacillus and Bifidobacterium genera are the most common microorganisms used in functional food industry (Champagne et al., 2011; Ozcan et al., 2021).

Fermented foods and drinks of dairy and non-dairy origin play an important role in diets worldwide (Aguilar \& Rivera, 2019). Most probiotics products originate from fermented dairy products, but recent studies have brought a new perspective of application which includes the use of fruit and vegetable juices (Rivera-Espinoza \& Gallardo-Navarro, 2010; Ellendersen et al., 2012; Aguilar \& Rivera, 2019).

The use of plant foods is justified, among many benefits, by the opportunity to supply different population groups such as vegetarians and people with lactose intolerance and dairy allergy (Prado et al., 2008; Alves et al., 2016). The possibility of offering a cholesterol-free and vitamin- and mineral-rich beverage, inherent in fruit-based products, is very promising (Soccol et al., 2010; Xu et al., 2019).

However, off-flavor development, which is caused by the growth of microorganisms and their fermentation, is most evident in the plant-based than dairy-based beverages (Alves et al., 2016). Choosing an adaptable strain and a plant technologically able to mask this effect is a challenging but essential goal in the industry of fruit-based probiotics products.

According Luckow et al. (2006) one of the most efficient ways to mask off-flavor is to use tropical fruit juices with pronounced flavor, such as passion fruit (Passiflora edulis Sims). This fruit is native from Latin America and Brazil and meets the criterion of regionality and practicality. Furthermore, its aroma and acidity is widely used and accepted in juices, jams and yogurts (Food and Agriculture Organization, 2013).

${ }^{1}$ Departamento de Nutrição, Universidade Federal da Paraíba - UFPB, Campus I, João Pessoa, PB, Brasil

${ }^{2}$ Rede Nordeste de Biotecnologia - RENORBIO, Universidade Federal Rural de Pernambuco - UFRPE, Recife, PE, Brasil

${ }^{3}$ Departamento de Nutrição, Universidade Federal de Pernambuco - UFPE, Recife, PE, Brasil

${ }^{4}$ Departmento de Medicina Tropical, Universidade Federal de Pernambuco - UFPE, Recife, PE, Brasil

*Corresponding author: ckrodrigues@hotmail.com 
The acceptance of a beverage, however, depends not only on the choice of the substrate, but also on the adaptation of the probiotic strain to it, in this case to the juice. In this sense, Lacticaseibacillus case $i$ has been successfully used in non-dairy fermented probiotic beverages with good amount of colony forming units (CFU) and good masking results (Ellendersen et al., 2012; Alves et al., 2016).

The presence of fermentable carbohydrate as raw materials is an additional good way to promote symbiosis (Bultosa, 2016). The addition of galacto-oligosaccharide, fructo-oligosaccharide, inulin, and, more recently, yam (Dioscorea sp.) are good options (Huang et al., 2012; Vijaya Kumar et al., 2015).

Yam is an extremely popular tuber in African countries and Brazil. It has been studied by its interesting functional properties which make it an anti-obesity, antioxidant and anti-inflammatory agent, modulator of immune responses and intestinal absorption of lipids, and more recently suggested prebiotic agent. Studies point that yam can be added to foods to provide better nutritional intake and add functional properties or promote symbiosis (Huang et al., 2012; Brownawell et al., 2012).

Thus, in view of the current market demand of non-dairy and probiotic foods with prioritization of the sustainability and regionality criteria, this study aimed to develop a non-dairy functional beverage containing $L$. casei using passion fruit and yam flour (Dioscorea cayenensis Lam).

\section{Materials and methods}

The raw materials used in this study were obtained from the Pernambuco Supply and Logistics Center (CEASA-PE) in a single batch.

\subsection{Obtaining passion fruit juice}

Passion fruit samples were selected, weighed in an electronic scale, washed in running water and sanitized with chlorinated water (200 ppm - 15 minutes), then washed with clean water, and cut. The pulp was homogenized in semi-industrial blender for a few seconds. The pulp was manually sifted and then diluted in mineral water at a ratio of $31 \%$ for adequacy Brix (6.00), according to criteria established by the Brazilian Legislation for Tropical Juices (Brasil, 2003).

\subsection{Obtaining yam flour}

Briefly, Yam samples were washed and scrubbed in running water and sanitized with chlorinated water (200 ppm - 15 minutes). Then, they were peeled, sliced, crushed and pulverized. The yam flour obtained was bleached and dried. Table 1 shows its proximate composition. Microbiological safety was evaluated for coliforms at $45^{\circ} \mathrm{C}$, coagulase-positive staphylococci, Bacillus cereus and Salmonella $\mathrm{sp} / 25 \mathrm{~g}$.

\subsection{Activation and viability of Lacticaseibacillus casei}

Lacticaseibacillus casei DN-114 001 lyophilizate was inoculated in a selective medium for lactobacilli (MRS - Man, Rogosa and Sharpe) at $37^{\circ} \mathrm{C}$ for 72 hours under anaerobic conditions and
Table 1. Chemical analysis of yam flour (Dioscorea cayenensis).

\begin{tabular}{lc}
\hline \multirow{2}{*}{ Analysis } & Yam Flour \\
\cline { 2 - 2 } & g.100 $\mathrm{g}^{-1}\left( \pm \mathrm{SD}^{*}\right)$ \\
\hline Moisture & $3.31 \pm 0.01$ \\
Ash & $4.60 \pm 0.07$ \\
Protein & $8.57 \pm 0.25$ \\
Lipid & $0.61 \pm 0.08$ \\
Carbohydrate & $81.68 \pm 0.40$ \\
Fiber & $10.70 \pm 0.02$ \\
Starch & $74.50 \pm 0.10$ \\
Sugars - total and reducing & $\mathrm{Tr}^{* *}$ \\
Total energy (kcal) & $366.53 \pm 0.24$ \\
pH & $5.85 \pm 0.01$ \\
Acidity & $2.24 \pm 0.05$ \\
\hline
\end{tabular}

${ }^{*}$ SD: Standard Deviation; ${ }^{*}$ Tr: traits.

adjusted to the turbidity of a $0.5 \mathrm{McF}$ arland standard which corresponds to $1.5 \times 10^{8} \mathrm{CFU} \cdot \mathrm{mL}^{-1}$ (McFarland, 1907). The viability of the strains was tested by the multiple-tube dilution method to $10^{-7}$ and $1 \mathrm{~mL}$ of substrate was inoculated onto MRS agar for depth at $37^{\circ} \mathrm{C}$ for 72 hours under anaerobic conditions. The CFU were counted and the results expressed as $\log \mathrm{CFU} \cdot \mathrm{mL}^{-1}$.

\subsection{Development of plant-based probiotic beverage}

Beverages were developed from the addition of three different concentrations of yam flour $(2.0 \%, 3.5 \%$ and $5.0 \%)$ into previously pasteurized $\left(72{ }^{\circ} \mathrm{C}-5 \mathrm{~min}\right)$ passion fruit juice. L. casei inoculum was added at $2 \%$, corresponding to $3.0 \times 10^{6} \mathrm{CFU} \cdot \mathrm{mL}^{-1}$. Fermentation occurred at $37 \pm 2{ }^{\circ} \mathrm{C}$ for 48 hours. The hydrogen potentials $(\mathrm{pH})$ range was monitored with a potentiometer (Mettler - DL 12) (Association of Official Analytical Chemists, 2002). The beverages were cooled at $10 \pm 2{ }^{\circ} \mathrm{C}$. Two controls were established, namely: 1. C - juice only; and 2. C+ - positive control (juice with addition of $L$. casei).

\subsection{Physical, chemical and microbiological analyses}

Moisture, protein (P), lipid (L), ash, total carbohydrate (TC), and fiber content were analyzed in triplicate and averages were calculated. Content was expressed in g/100 g. Total energy (TE) was calculated by the equation: $\mathrm{TE}=(\mathrm{TC} \times 4)+(\mathrm{Px} 4)+(\mathrm{Lx} 9)$. The microbiological safety was evaluated for coliforms at $45^{\circ} \mathrm{C}$ and Salmonella in 25 and $50 \mathrm{~mL}$ of beverage. All analyses were performed in triplicate (Association of Official Analytical Chemists, 2002; Brasil, 2003).

\subsection{Sensory analysis}

Sensory tests included the analysis of acceptability, purchase intent and preference ranking and were performed only after approval by the Research Ethics Committee (protocol 15312113.2.0000.5208/2013).

Samples were stored for $24 \mathrm{~h}$ at $10 \pm 2{ }^{\circ} \mathrm{C}$ prior to evaluation. Samples of $50 \mathrm{~mL}$ of the beverages were placed on small white cups, coded with three-digit random numbers, and served immediately after taken out of refrigerated storage. Mineral 
water was provided between consecutive samples for mouth rinsing. The test was conducted in an individual well-lit cabin.

Acceptance as to appearance, color, taste, aroma and overall acceptability was evaluated through a 9-point hedonic scale (1: dislike extremely; 9: like extremely). The taster was asked to list beverages in a descending order of preference. Attitude regarding purchase consumer purchase intent was assessed using a 5-point scale (1: certainly not; 5: certainly yes).

To calculate the acceptability index (AI), the following mathematical expression was used: $\mathrm{AI}=\mathrm{X} \times 100 / \mathrm{n}^{\circ}$, where: $\mathrm{X}=$ mean score attributed by tasters, and $\mathrm{n}^{\circ}=$ highest score attributed by tasters (Meilgaard et al., 2007).

The following analyses were made only with the beverage that presented greater acceptability in the sensory analysis. The beverages used came from a single manufacturing batch in order to ensure comparable results.

\subsection{Shelf-life evaluation}

Shelf life of a beverage was measured according to L. casei viability and $\mathrm{pH}$ evaluation on days $0,7,14,21$ and 28 after fermentation. The $\mathrm{pH}$ range was monitored with a potentiometer (Mettler - DL 12) (Association of Official Analytical Chemists, 2002) and the viability of the strains was tested by the multipletube dilution methods to $10^{-7}$ and $1 \mathrm{~mL}$ of substrate was inoculated on MRS agar for depth at $37^{\circ} \mathrm{C}$ for 72 hours under anaerobic conditions. The $\mathrm{CFU}$ were counted and the results expressed as $\log$ CFU.mL $L^{-1}$.

\subsection{Lacticaseibacillus casei survival to in vitro simulated gastrointestinal digestion}

In vitro gastrointestinal digestion was performed by the use and modification of two methods (Liserre et al., 2007; Santos et al., 2011). Briefly, the selected sample was first diluted in saline $0.85 \%(1: 9)$ and then an acidic solution of pepsin ( $3 \mathrm{~g} / \mathrm{L} ; \mathrm{pH} 2.5$ ) added to the sample to measure the resistance to acid and pepsin (gastric phase). The mixture was incubated on a shaker ( $150 \mathrm{rpm}$ ) at $37^{\circ} \mathrm{C}$ for 120 minutes. To measure the resistance to bile (enteric phase), a basic solution of bovine bile ( $3 \mathrm{~g} / \mathrm{L} ; \mathrm{pH} 7.5$ ) was added to the sample and the mixture was incubated as described before $\left(150 \mathrm{rpm}-37^{\circ} \mathrm{C}-120\right.$ and 240 minutes). After that the viability of $L$. casei was checked. Tests were performed in quadruplicate and the control consisted of sample incubation without change of $\mathrm{pH}$ or addition of enzymes.

\subsection{Statistical analysis}

All assays were made in triplicate or quadruplicate and the results were expressed as means or means \pm standard deviations. The results of the bacterial viability and sensory analyses were evaluated by analysis of variance (ANOVA), considering yam flour concentration. Paired-sample t-tests with 95\% confidence intervals $(\mathrm{p}<0.05)$ were used to compare the means of the attributes evaluated when applicable. For the hedonic scale, the decision criterion for the index to be well accepted was $70 \%$ or higher (Meilgaard et al., 2007).

\section{Results}

\subsection{Beverage fermentation process}

The fermentation of the beverages was monitored over 72 hours. Figure 1 shows that there was a temporal variation in $\mathrm{pH}$ values. No significant differences were observed between 24 and 72 hours (*time axis) for any sample, indicating that the minimum $\mathrm{pH}$ values were achieved in $48 \mathrm{~h}$. A comparison between beverages with $2.0 \%$ and $5.0 \%$ of yam flour showed that there was an increase in $\mathrm{pH}(\#)(\mathrm{p}=0.01)$ proportional to the amount of yam flour added to the beverage. Statistical analyses indicate no difference in the evolution of $\mathrm{pH}$ between samples $\mathrm{C}+$ and $2 \%\left({ }^{*} \mathrm{pH}\right.$ axis). All other means were significantly different.

\subsection{Physical, chemical and microbiological analyses}

The physical and chemical composition of the beverages is shown in Table 2. The addition of yam flour increased the amount of ash, protein, carbohydrate and fiber in the beverages in relation to the control.

\subsection{Sensory analysis}

Sixty-two untrained panelists participated in the sensory tests. The mean age was $22.4 \pm 4.19$ years, and the majority $(82.6 \%)$ was female. The acceptance rate of each attribute of the beverages was evaluated and results are presented in Table 3.

Differences in the perception of the attributes were evident. The scores attributed to color, appearance, and aroma were superior to those attributed to taste and overall acceptability. The scores attributed for color and appearance varied between "like very much" and "like extremely", those for aroma varied from "like moderately" to "like very much", and those for taste and overall acceptability varied between "neither like nor dislike" and "dislike lightly".

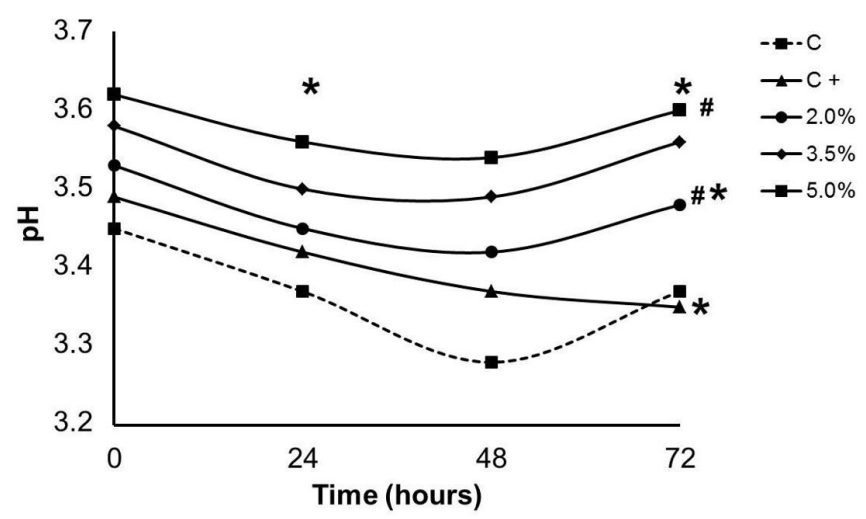

Figure 1. Hydrogen potentials $(\mathrm{pH})$ variation during fermentation of non-dairy functional beverages based on passion fruit (Passiflora edulis Sims) and different concentrations yam flour (Dioscorea cayenensis). $\mathrm{C}=$ control (juice only), $\mathrm{C}+=$ positive control (juice with addition of $L$. casei), 2.0, 3.5 and $5.0 \%=$ concentration of yam flour in the beverages. Time axis: asterisks $\left(^{*}\right)=$ no significant difference $(\mathrm{p}>0.05)$. $\mathrm{pH}$ axis: asterisks $\left({ }^{*}\right)=$ no significant difference $(\mathrm{p}>0.05)$. All other averages differ significantly $(\mathrm{p}<0.05)$. The symbol \# indicates significant difference $(\mathrm{p}=0.01)$. 
Table 2. Physical-chemical composition of a non-dairy functional beverage based on passion fruit (Passiflora edulis Sims) and different concentrations yam flour (Dioscorea cayenensis).

\begin{tabular}{|c|c|c|c|c|}
\hline \multirow{3}{*}{ Analysis } & \multirow{3}{*}{$\mathrm{C}^{* *}$} & \multicolumn{3}{|c|}{ Concentration of yam flour } \\
\hline & & \multicolumn{3}{|c|}{ g. $100 \mathrm{~g}^{-1}\left( \pm \mathrm{SD}^{*}\right)$} \\
\hline & & $2.0 \%{ }^{\star *}$ & $3.5 \% * *$ & $5.0 \%^{\star *}$ \\
\hline Moisture & $93.43 \pm 0.11$ & $93.50 \pm 0.10$ & $92.06 \pm 0.08$ & $90.63 \pm 0.11$ \\
\hline Ash & $0.18 \pm 0.09$ & $0.27 \pm 0.09$ & $0.34 \pm 0.12$ & $0.41 \pm 0.08$ \\
\hline Protein & $0.22 \pm 0.15$ & $0.40 \pm 0.20$ & $0.53 \pm 0.30$ & $0.66 \pm 0.16$ \\
\hline Lipid & $0.20 \pm 0.03$ & $0.21 \pm 0.06$ & $0.22 \pm 0.04$ & $0.23 \pm 0.04$ \\
\hline Carbohydrate & $4.00 \pm 0.11$ & $5.62 \pm 0.30$ & $6.85 \pm 0.28$ & $8.07 \pm 0.20$ \\
\hline Fiber & $1.66 \pm 0.06$ & $1.89 \pm 0.02$ & $2.05 \pm 0.04$ & $2.21 \pm 0.02$ \\
\hline Total energy (kcal) & $18.64 \pm 0.15$ & $25.97 \pm 0.19$ & $31.5 \pm 0.21$ & $36.99 \pm 0.13$ \\
\hline
\end{tabular}

${ }^{*}$ SD: Standard Deviation; ${ }^{* *} \mathrm{C}$ : control (juice only), $2.0,3.5$ and $5.0 \%$ indicates the concentration of yam flour in the beverages.

Table 3. Index of acceptability (\%) of a non-dairy functional beverage based on passion fruit (Passiflora edulis Sims) and different concentrations yam flour (Dioscorea cayenensis).

\begin{tabular}{llcl}
\hline \multirow{2}{*}{ Attributes } & \multicolumn{3}{c}{ Index of acceptability (\%) } \\
\cline { 2 - 4 } & \multicolumn{3}{c}{ Concentration of yam flour } \\
\cline { 2 - 4 } & $2.0 \%^{*}$ & $3.5 \%^{*}$ & $5.0 \%^{*}$ \\
\hline Color & 85.66 & 86.38 & 85.48 \\
Appearance & 82.44 & 80.65 & 82.26 \\
Aroma & 74.19 & 73.48 & 74.01 \\
Taste & 49.28 & 43.37 & 42.29 \\
Overall liking & 56.81 & 51.79 & 51.79 \\
\hline
\end{tabular}

${ }^{*} 2.0,3.5$ and $5.0 \%$ indicates the concentration of yam flour in the beverages. The mean scores assigned to purchase intent were $2.53 \pm 1.26,2.21 \pm 1.09$ and $2.11 \pm 1.06$ respectively, for beverages with a concentration of $2.0 \%, 3.5 \%$ and $5.0 \%$ of yam flour.

On the issue of preference, a total of $46.7 \%$ of people said they preferred the beverage containing $2.0 \%$ of yam flour. Each of the other concentrations were preferred by $26.65 \%$ of the evaluators.

The following analyses were performed with the beverage that had greater acceptability in the sensory analysis, namely, the one with $2.0 \%$ of yam flour.

\subsection{Shelf-life evaluation}

The beverage with $2.0 \%$ of yam flour was evaluated over 28 days of storage. Figure 2 shows the variation in $\mathrm{pH}$ of the beverage through time. There was a progressive increase in the acidification of the medium for seven days, and from this point on, there was a slight increase in the $\mathrm{pH}$ values, and then they remained nearly constant up to 28 days.

The count of lactic acid bacteria was carried out on days 0 , $7,14,21$ and 28 of storage and showed 7.67, 6.50, 7.07, 6.32 and 6.41 log CFU.mL ${ }^{-1}$, respectively. Numbers of CFU did not differ statistically in the days 7, 21 and $28\left(^{*}\right)$. No contamination was detected during storage.

\subsection{Resistance of L. casei to in vitro simulated gastrointestinal tract conditions}

The mean numbers of $L$. casei CFU obtained at 0 and 28 days are shown in Figure 3. The mean values were 7.48, 6.57,

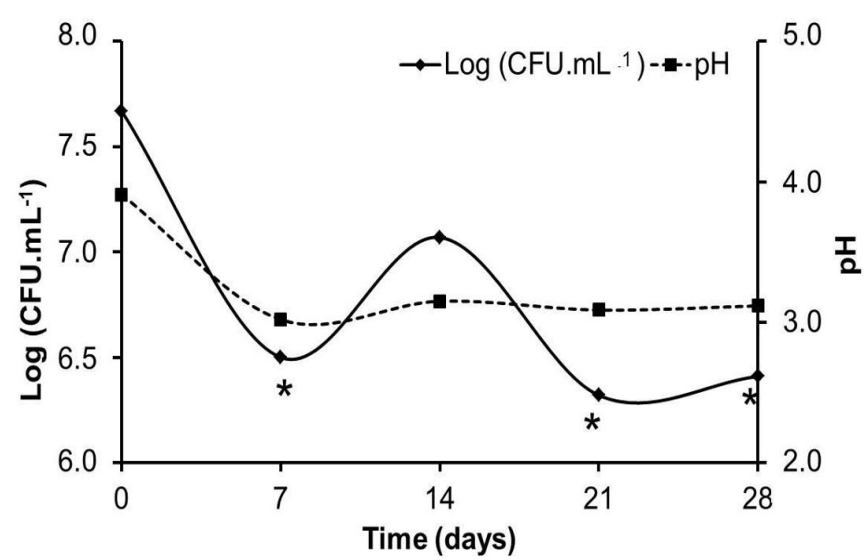

Figure 2. Hydrogen potentials $(\mathrm{pH})$ variation and colony forming units (Log CFU.mL ${ }^{-1}$ ) count during shelf life of a non-dairy functional beverage based on passion fruit (Passiflora edulis Sims) and 2\% of yam flour (Dioscorea cayenensis). Asterisks ${ }^{*}$ ) indicates no significant difference $(\mathrm{p}>0.05)$.

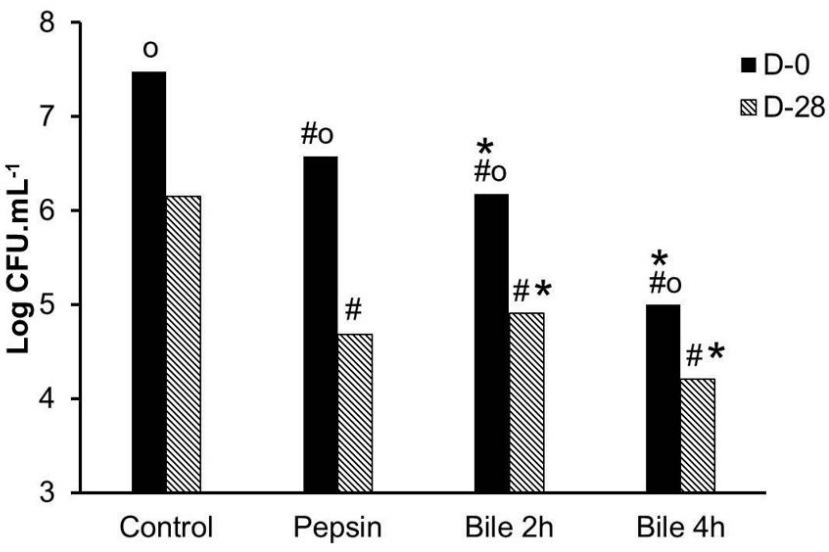

Figure 3. Resistance of $L$. casei to in vitro simulated gastrointestinal tract conditions of a non-dairy functional beverage based on passion fruit (Passiflora edulis Sims) and 2\% of yam flour (Dioscorea cayenensis). Colony forming units $=\log C F U \cdot \mathrm{mL}^{-1}$. D- $0=$ beverage preparation day. D-28 $=28$ th day of storage. Asterisks $\left({ }^{*}\right)=$ samples differ significantly between them on the same time. The symbol \# indicates that samples differ significantly of control. The symbol "O" indicates that samples differ significantly with time $(\mathrm{p}<0.05)$. 
6.18 and 5.00 log CFU.mL $\mathrm{mL}^{-1}$ for control, pepsin, bile $2 \mathrm{~h}$, and bile $4 \mathrm{~h}$ treatments at day 0 , respectively, and $6.15,4.68,4.90$ and $4.20 \log$ CFU.mL $\mathrm{m}^{-1}$ for control, pepsin, bile $2 \mathrm{~h}$, and bile $4 \mathrm{~h}$ treatments at day 28 , respectively.

All treatments differed significantly from control (\#) in both periods. The same occurred in the bile $2 \mathrm{~h}$ and bile $4 \mathrm{~h}\left({ }^{*}\right)$ treatments. The count on day 28 was lower than in that in day 0 for all treatments $(\mathrm{o})(\mathrm{p}<0.05)$.

\section{Discussion}

\subsection{Beverage fermentation process}

In the present study, the minimum $\mathrm{pH}$ was found at $48 \mathrm{~h}$ of fermentation, which suggest maximum production of lactic acid by L. casei. A study on optimization of the fermentation process in tomato juice also showed a better state of L. case $i$ at 48 hours under $30^{\circ} \mathrm{C}$, similarly to our present findings (Pereira et al., 2011).

$\mathrm{pH}$ values increased proportionally to the amount of yam flour added, but the addition of $2 \%$ yam flour provided no interference in the metabolic behavior of $L$. casei when compared to control without yam flour. Some studies show a decrease in viability of probiotics during storage in several conditions, including acid environments (Champagne \& Gardner, 2008; Rivera-Espinoza \& Gallardo-Navarro, 2010). The reduction in acidity caused by yam flour could, therefore, promote a better resistance and adaptation of the microorganism and thus a longer viability. Strategic use of plant-based milk has shown similar results. These types of products illustrate the emerging probiotic matrices (Rasika et al., 2021).

\subsection{Chemical composition and microbiological analysis}

All beverages in this study can be considered good sources of fiber as they provide $3.78 \mathrm{~g}(15.1 \%), 4.10 \mathrm{~g}(16.4 \%)$ and $4.42 \mathrm{~g}(17.7 \%)$ of fibers in portions of $200 \mathrm{~mL}$ of the beverages with $2.0 \%, 3.5 \%$ and $5.0 \%$ yam flour, respectively.

In order to be considered a good source of fiber, foods must provide at least $10 \%$ of the daily recommended dietary fiber intake. Based on the recommendation of the dietary reference intakes, which is $25 \mathrm{~g}$ fiber/day for young adults, a food source must provide at least $3 \mathrm{~g} /$ fiber by portion (Institute of Medicine, 2005).

The tests of microbiological safety of the beverages showed negative results in all analyses, indicating excellence in hygiene and sanitary measures during the experiments.

\subsection{Sensory analysis}

This study was effective to demonstrate, for the first time, that passion fruit alone can mask fermentation odors. The pleasant and usual odor of the fruit prevailed, thus indicating good chances of acceptance. This finding, and precisely the satisfactory scores for aroma, was a highlight of this study.

The addition of probiotic organisms in non-dairy matrices leads to the production of different metabolic components such as lactic acid and other metabolites during fermentation and over the storage period. Probiotic bacteria ferment the carbohydrate of food and this leads to changes in flavor, aroma and taste of the probiotic product, adversely affecting the sensory properties of the product (Mohammadi et al., 2011).

In this study, purchase intention scores were around 2 (probably not), indicating that most of the tasters were not inclined to buy the beverages, showing that food consumption is strongly related to the taste of the food.

This association is already well reported in the literature. Although the decision to consume a food depends on a variety of sensory properties, such as odor and texture, the flavor allows individuals to discern and make choices that take into account nutritional and safety aspects, such as the presence of toxic substances, which tend to be rejected (Galindo et al., 2012).

Related studies reinforce this premise by showing that the preference of fermented beverages was closely associated with the assessment of flavor and aroma of the food (Champagne \& Gardner, 2008; Prado et al., 2008; Pereira et al., 2011; Martins et al., 2013; Alves et al., 2016).

In this sense, it is important to clarify that the lower taste and overall acceptance scores found in this study were certainly not explained only by the fact that the product was unknown in Brazil (where the sensory tests took place), especially among the age group studied, but also by the fact that sugar was not added to the product, and adding sugar is common habit around the world (Cunha et al., 2013).

Brazil is one of the countries that is still undergoing nutritional transitions, and the consumption of sugar is considered high. Some researchers reported difficulties in the attempt to change food habits in groups in developing countries (Cunha et al., 2013; Avery et al., 2015; Singh et al., 2015).

One of the strategies that can help to change this scenario is the association with products presenting functional qualities, such as healthy properties (Luckow et al., 2006). Another strategy is to prevent the interaction of the microorganism with the vehicle through immobilization and encapsulation of probiotic bacteria by different techniques (chemical, physical, or both) and materials (alginate, chitosan, carrageenan, starches, etc.) (Choińska-Pulit et al., 2015).

A successful example was reported using poly- $\gamma$-glutamic acid to immobilize Bifidobacterium strains in acidic orange and pomegranate fruit juices, thus indicating an alternative for future experiments (Bhat et al., 2015).

Finally, from all beverages submitted to sensorial tests, the one with $2 \%$ of yam flour had the best evaluations. The preference for the beverage with less flour content probably was due texture since there was no significant difference in any of the other sensory parameters. Comments about roughness in mouth during sensory tests of beverages with higher concentration of yam flour support this idea.

In face to improve the knowledge about this new kind of food we suggest the inclusion of a trained panel and temporal methods in further sensory studies (Silva et al., 2018) 


\subsection{Shelf-life evaluation}

The shelf-life evaluation showed that $L$. casei presented excellent adaptation to passion fruit-based beverage with yam during the whole storage period. Many studies point that viability of probiotics in plant-based products during shelf life has been satisfactory. In particular the use of L. casei present excellent results, proving to be viable both in the formulation of dairy and non-dairy products (Ricci et al., 2018; Balthazar et al., 2018; García et al., 2019; Ozcan et al., 2021; Rasika et al., 2021).

The diauxic growth curve of L. casei (Figure 2) showed a positive effect of diauxic behavior on the shelf life of the beverage. Until 28 days of storage beverages had the same viability of lactobacilli found on the 7th day of storage. As diauxic growth is diphasic and generally reflects exchange of the substrate (most common carbohydrate) as an adaptation in growth and survival and microorganisms use the available sugars sequentially, not simultaneously, we suggest that the addition of yam was crucial to the increased supply of carbohydrates and consequently promoted the extended shelf life of the beverage presented here (Solopova et al., 2014).

Beverages also presented the CFU numbers $>10^{6} \cdot \mathrm{mL}^{-1}$, a value considered enough to exert positive effects on the body (Fooks \& Gibson, 2002; Zendeboodi et al., 2020).

\subsection{Resistance of L. casei to in vitro simulated gastrointestinal tract conditions}

Despite the decrease in viable cells, L. casei showed to have adapted to the beverage studied and to extreme simulated conditions.

Most of fermented products exhibit low cell viability after oral administration because bacteria do not survive the acid environment of the stomach (Klayraung et al., 2009).

The bile released in the small intestine is also harsh to probiotic survival, for it causes their lipid-rich cell membrane to be destroyed (Gilliland \& Speck, 1977).

Lactic bacteria are high-demanding microorganisms because they require various essential amino acids and vitamins for growing. They are also the principal microorganisms responsible for the natural fermentation of vegetables (Linares et al., 2017; Ricci et al., 2018).

These conditions may have positively affected the microorganisms' adaptation to the beverage in the present study since the growing medium was rich in vitamins and minerals and fermentable material from passion fruit juice and yam flour.

\section{Conclusion}

Consumption of plant-based beverages with probiotics is an alternative to replace dairy products in diet. Passion fruit and yam flour showed to be excellent raw materials to be explored and used in combination to promote the probiotic survival and mask the off-flavor characteristic of fermentation, thus being promising alternatives in non-dairy probiotic products development. This study showed that the color, aroma and appearance of the beverage were well accepted by consumers.
An excellent shelf life and the adaptation to the acid conditions of the beverage as well as the resistance of L. casei to in vitro simulated gastrointestinal tract conditions were demonstrated. Further tests and modifications in the preparation of the functional beverage, such as microencapsulation, are recommended to improve the acceptance and of the product and promote an enhanced viability of L. casei.

\section{Acknowledgements}

The authors thank the Coordenação de Aperfeiçoamento de Pessoal de Nível Superior (CAPES) and the Conselho Nacional de Desenvolvimento Científico e Tecnológico (CNPq) for financial support.

\section{References}

Aguilar, E. F., \& Rivera, E del PF. (2019). Assessment of the use of the hydrolyzed liquid fraction of the kiwicha grain in the fermentation process of probiotic drinks from tarwi juice: microbiological, chemical and sensorial analysis. Food Science and Technology, 39(3), 592-598. http://dx.doi.org/10.1590/fst.33617.

Alves, N. N., Messaoud, G. B., Desobry, S., Costa, J. M. C., \& Rodrigues, S. (2016). Effect of drying technique and feed flow rate on bacterial survival and physicochemical properties of a non-dairy fermented probiotic juice powder. Journal of Food Engineering, 189, 45-54. http://dx.doi.org/10.1016/j.jfoodeng.2016.05.023.

Association of Official Analytical Chemists - AOAC. (2002) Official methods of analysis (17th ed.). Arlington: AOAC International.

Avery, A., Bostock, L., \& McCullough, F. (2015). A systematic review investigating interventions that can help reduce consumption of sugar-sweetened beverages in children leading to changes in body fatness. Journal of Human Nutrition and Dietetics, 28(Suppl. 1), 5264. http://dx.doi.org/10.1111/jhn.12267. PMid:25233843.

Balthazar, C. F., Silva, H. L. A., Esmerino, E. A., Rocha, R. S., Moraes, J., Carmo, M. A. V., Azevedo, L., Camps, I., K D Abud, Y., Sant'Anna, C., Franco, R. M., Freitas, M. Q., Silva, M. C., Raices, R. S. L., Escher, G. B., Granato, D., Senaka Ranadheera, C., Nazarro, F., \& Cruz, A. G. (2018). The addition of inulin and Lactobacillus casei 01 in sheep milk ice cream. Food Chemistry, 246, 464-472. http://dx.doi. org/10.1016/j.foodchem.2017.12.002. PMid:29291874.

Bhat, A. R., Irorere, V. U., Bartlett, T., Hill, D., Kedia, G., Charalampopoulos, D., Nualkaekul, S., \& Radecka, I. (2015). Improving survival of probiotic bacteria using bacterial poly- $\gamma$-glutamic acid. International Journal of Food Microbiology, 196, 24-31. http://dx.doi.org/10.1016/j. ijfoodmicro.2014.11.031. PMid:25506798.

Brasil. (2003, September 9). Regulamento Técnico para Fixação dos Padrões de Identidade e Qualidade Gerais para Suco Tropical (Instrução normativa $\mathrm{n}^{\circ} 12$, de 4 de setembro de 2003). Diário Oficial [da] República Federativa do Brasil.

Brownawell, A. M., Caers, W., Gibson, G. R., Kendall, C. W., Lewis, K. D., Ringel, Y., \& Slavin, J. L. (2012). Prebiotics and the health benefits of fiber: current regulatory status, future research, and Goals. The Journal of Nutrition, 142(5), 962-974. http://dx.doi.org/10.3945/ jn.112.158147. PMid:22457389.

Bultosa, G. (2016). Functional foods: dietary fibers, prebiotics, probiotics, and synbiotics. In G. W. Smithers (Ed.), Reference module in food science. Amsterdam: Elsevier. http://dx.doi.org/10.1016/B978-008-100596-5.00245-6. 
Champagne, C. P., \& Gardner, N. J. (2008). Effect of storage in a fruit drink on subsequent survival of probiotic lactobacilli to gastrointestinal stresses. Food Research International, 41(5), 539-543. http://dx.doi.org/10.1016/j.foodres.2008.03.003.

Champagne, C. P., Ross, R. P., Saarela, M., Hansen, K. F., \& Charalampopoulos, D. (2011). Recommendations for the viability assessment of probiotics as concentrated cultures and in food matrices. International Journal of Food Microbiology, 149(3), 185-193. http://dx.doi.org/10.1016/j. ijfoodmicro.2011.07.005. PMid:21803436.

Choińska-Pulit, A., Mituła, P., Śliwka, P., Łaba, W., \& Skaradzińska, A. (2015). Bacteriophage encapsulation: Trends and potential applications. Trends in Food Science \& Technology, 45(2), 212-221. http://dx.doi.org/10.1016/j.tifs.2015.07.001.

Cunha, D. B., Souza, B. S. N., Pereira, R. A., \& Sichieri, R. (2013). Effectiveness of a randomized school-based intervention involving families and teachers to prevent excessive weight gain among adolescents in Brazil. PLoS One, 8(2), e57498. http://dx.doi.org/10.1371/journal. pone.0057498. PMid:23451237.

Daliri, E. B.-M., \& Lee, B. H. (2015). New perspectives on probiotics in health and disease. Food Science and Human Wellness, 4(2), 56-65. http://dx.doi.org/10.1016/j.fshw.2015.06.002.

Ellendersen, L. S. N., Granato, D., Bigetti Guergoletto, K., \& Wosiacki, G. (2012). Development and sensory profile of a probiotic beverage from apple fermented with Lactobacillus casei. Engineering in Life Sciences, 12(4), 475-485. http://dx.doi.org/10.1002/elsc.201100136.

Food and Agriculture Organization - FAO. (2013). FAOSTAT. Rome: FAO.

Fooks, L. J., \& Gibson, G. R. (2002). Probiotics as modulators of the gut flora. British Journal of Nutrition, 88(S1, Suppl. 1), S39-S49. http:// dx.doi.org/10.1079/BJN2002628. PMid:12215180.

Galindo, M. M., Schneider, N. Y., Stähler, F., Töle, J., \& Meyerhof, W. (2012). Taste preferences. Progress in Molecular Biology and Translational Science, 108, 383-426. http://dx.doi.org/10.1016/ B978-0-12-398397-8.00015-0. PMid:22656385.

García, C., Bautista, L., Rendueles, M., \& Díaz, M. (2019). A new synbiotic dairy food containing lactobionic acid and Lactobacillus casei. International Journal of Dairy Technology, 72(1), 47-56. http:// dx.doi.org/10.1111/1471-0307.12558.

Gilliland, S. E., \& Speck, M. L. (1977). Deconjugation of bile acids by intestinal lactobacilli. Applied and Environmental Microbiology, 33(1), 15-18. http://dx.doi.org/10.1128/AEM.33.1.15-18.1977. PMid:13710.

Hotel, A. C., \& Córdoba, A. (2001). Health and nutritional properties of probiotics in food including powder milk with live lactic acid bacteria. Prevention, 5(1), 1-10.

Huang, C.-H., Cheng, J.-Y., Deng, M.-C., Chou, C. H., \& Jan, T. R. (2012). Prebiotic effect of diosgenin, an immunoactive steroidal sapogenin of the Chinese yam. Food Chemistry, 132(1), 428-432. http://dx.doi.org/10.1016/j.foodchem.2011.11.016. PMid:26434311.

Institute of Medicine - IOM. (2005) Dietary Reference Intakes for energy, carbohydrate, fiber, fat, fatty acids, cholesterol, protein, and amino acids (2nd ed.). Washington: National Academies Press.

Klayraung, S., Viernstein, H., \& Okonogi, S. (2009). Development of tablets containing probiotics: Effects of formulation and processing parameters on bacterial viability. International Journal of Pharmaceutics, 370(1-2), 54-60. http://dx.doi.org/10.1016/j.ijpharm.2008.11.004. PMid:19059323.

Linares, D. M., Gómez, C., Renes, E., Fresno, J. M., Tornadijo, M. E., Ross, R. P., \& Stanton, C. (2017). Lactic acid bacteria and bifidobacteria with potential to design natural biofunctional health-promoting dairy foods. Frontiers in Microbiology, 8, 846. http://dx.doi.org/10.3389/ fmicb.2017.00846. PMid:28572792.
Liserre, A. M., Ré, M. I., \& Franco, B. D. G. M. (2007). Microencapsulation of Bifidobacterium animalis subsp. lactis in modified alginate-chitosan beads and evaluation of survival in simulated gastrointestinal conditions. Food Biotechnology, 21(1), 1-16. http://dx.doi. org/10.1080/08905430701191064.

Luckow, T., Sheehan, V., Fitzgerald, G., \& Delahunty, C. (2006). Exposure, health information and flavour-masking strategies for improving the sensory quality of probiotic juice. Appetite, 47(3), 315-323. http:// dx.doi.org/10.1016/j.appet.2006.04.006. PMid:16857295.

Martins, E. M. F., Ramos, A. M., Vanzela, E. S. L., Stringheta, P. C., de Oliveira Pinto, C. L., \& Martins, J. M. (2013). Products of vegetable origin: a new alternative for the consumption of probiotic bacteria. Food Research International, 51(2), 764-770. http://dx.doi.org/10.1016/j. foodres.2013.01.047.

McFarland, J. (1907). The nephelometer: an instrument for estimating the number of bacteria in suspensions used for calculating the opsonic index and for vaccines. J Am Med Assoc, XLIX(14), 1176. http://dx.doi.org/10.1001/jama.1907.25320140022001f.

Meilgaard, M. C., Civille, G. V., \& Carr, B. T. (2007). Sensory evaluation techniques (4th ed.). Boca Raton: CRC Press.

Mohammadi, R., Mortazavian, A. M., Khosrokhavar, R., \& da Cruz, A. G. (2011). Probiotic ice cream: viability of probiotic bacteria and sensory properties. Annals of Microbiology, 61(3), 411-424. http:// dx.doi.org/10.1007/s13213-010-0188-z.

Ozcan, T., Ozdemir, T., \& Avci, H. R. (2021). Survival of Lactobacillus casei and functional characteristics of reduced sugar red beetroot yoghurt with natural sugar substitutes. International Journal of Dairy Technology, 74(1), 148-160. http://dx.doi.org/10.1111/14710307.12741.

Pereira, A. L. F., Maciel, T. C., \& Rodrigues, S. (2011). Probiotic beverage from cashew apple juice fermented with Lactobacillus casei. Food Research International, 44(5), 1276-1283. http://dx.doi.org/10.1016/j. foodres.2010.11.035.

Prado, F. C., Parada, J. L., Pandey, A., \& Soccol, C. R. (2008). Trends in non-dairy probiotic beverages. Food Research International, 41(2), 111-123. http://dx.doi.org/10.1016/j.foodres.2007.10.010.

Rasika, D. M., Vidanarachchi, J. K., Rocha, R. S., Balthazar, C. F., Cruz, A. G., Sant'Ana, A. S., \& Ranadheera, C. S. (2021). Plant-based milk substitutes as emerging probiotic carriers. Current Opinion in Food Science, 38, 8-20. http://dx.doi.org/10.1016/j.cofs.2020.10.025.

Ricci, A., Cirlini, M., Levante, A., Dall’Asta, C., Galaverna, G., \& Lazzi, C. (2018). Volatile profile of elderberry juice: effect of lactic acid fermentation using L. plantarum, L. rhamnosus and L. casei strains. Food Research International, 105, 412-422. http://dx.doi.org/10.1016/j. foodres.2017.11.042. PMid:29433231.

Rivera-Espinoza, Y., \& Gallardo-Navarro, Y. (2010). Non-dairy probiotic products. Food Microbiology, 27(1), 1-11. http://dx.doi.org/10.1016/j. fm.2008.06.008. PMid:19913684.

Santos, F. F., Almeida, M. A., Brumano, L. P., et al.(2011). Development of scientific technical report for registration of fermented milk with functional claim. Revista do Instituto de Latícinios Cândido Tostes, 383, 40-48. http://dx.doi.org/10.1016/j.foodres.2013.01.047.

Silva, H. L. A., Balthazar, C. F., Silva, R., Vieira, A. H., Costa, R. G. B., Esmerino, E. A., Freitas, M. Q., \& Cruz, A. G. (2018). Sodium reduction and flavor enhancer addition in probiotic prato cheese: Contributions of quantitative descriptive analysis and temporal dominance of sensations for sensory profiling. Journal of Dairy Science, 101(10), 8837-8846. http://dx.doi.org/10.3168/jds.201814819. PMid:30077456. 
Singh, G. M., Micha, R., Khatibzadeh, S., Shi, P., Lim, S., Andrews, K. G., Engell, R. E., Ezzati, M., \& Mozaffarian, D. (2015). Global, regional, and national consumption of sugar-sweetened beverages, fruit juices, and milk: a systematic assessment of beverage intake in 187 countries. PLoS One, 10(8), e0124845. http://dx.doi.org/10.1371/ journal.pone.0124845. PMid:26244332.

Soccol, C. R., Vandenberghe, L. P. S., Spier, M. R., Medeiros, A. B. P., Yamaguishi, C. T., Lindner, J. D., Pandey, A., \& Thomaz-Soccol, V. (2010). The potential of probiotics: a review. Food Technology and Biotechnology, 48(4), 413-434.

Solopova, A., Van Gestel, J., Weissing, F. J., Bachmann, H., Teusink, B., Kok, J., \& Kuipers, O. P. (2014). Bet-hedging during bacterial diauxic shift. Proceedings of the National Academy of Sciences of the United States of America, 111(20), 7427-7432. http://dx.doi.org/10.1073/ pnas.1320063111. PMid:24799698.
Vijaya Kumar, B., Vijayendra, S. V., \& Reddy, O. V. (2015). Trends in dairy and non-dairy probiotic products: a review. Journal of Food Science and Technology, 52(10), 6112-6124. http://dx.doi.org/10.1007/ s13197-015-1795-2. PMid:26396359.

Xu, X., Bao, Y., Wu, B., Lao, F., Hu, X., \& Wu, J. (2019). Chemical analysis and flavor properties of blended orange, carrot, apple and Chinese jujube juice fermented by selenium-enriched probiotics. Food Chemistry, 289, 250-258. http://dx.doi.org/10.1016/j. foodchem.2019.03.068. PMid:30955609.

Zendeboodi, F., Khorshidian, N., Mortazavian, A. M., \& da Cruz, A. G. (2020). Probiotic: conceptualization from a new approach. Current Opinion in Food Science, 32, 103-123. http://dx.doi.org/10.1016/j. cofs.2020.03.009. 